ペニシリン耐性菌によるムコーズス中耳炎例

成尾一彦・宮原裕・笹井 久德・松代 直樹

\title{
A Case of Adult Otitis Media Presenting with Bone Conduction Hearing Loss Due to Mucoid Type Penicillin-resistant Streptococcus Pneumoniae
}

\author{
Kazuhiko Nario, Hiroshi Miyahara, Hisanori Sasai and Naoki Matsushiro \\ (Osaka General Medical Center)
}

\begin{abstract}
A 65-year-old man complained of severe otalgia, occipital pain, hearing loss and otorrhea was referred to our hospital. Otoscopic examination demonstrated hyperemia and bulging of the left ear drum. The bacteria isolated from otorrhea was a mucoid type of Streptococcus pnemoniae. It was also penicillin-resistant Streptococcus pneumoniae (PRSP). The patient was diagnosed as having mucoid otitis media. Intravenous administration of piperacillin sodium (PIPC) diminished otalgia, occipital pain and otorrhea. However, the patient continued complain of hearing loss and a sensation of ear fullness. Due to acute sensorineural hearing loss, the patient was administered steroids. Nevertheless, bone conduction hearing loss persisted. This is the first report of otitis media demonstrating not only the mucoid type of Streptococcus pnemoniae but also PRSP.
\end{abstract}

Key words : mucoid otitis media, mucoid type Streptococcus pnemoniae, penicillin-resistant Streptococcus pneumoniae

はじめに

ムコーズス中耳炎は抗生物質がなかった時代には頭蓋 内合併症や急性乳様突起炎を起こし猛威をふるってい た ${ }^{12)}$ が，抗生物質の普及以来激減した. ムコーズス中耳 炎は肺炎球菌が起炎菌である。肺炎球菌は抗生物質に対 する耐性化が急速に進行しており，ペニシリン耐性肺炎 球菌 (PRSP : penicillin-resistant Streptococcus pneumoniae) が急増している.ムコーズス中耳炎は肺炎球菌のらちム コイド型が原因菌で，ムコイド型は耐性化しにくいとい われ，ムコイド型でかつ PRSP という報告はなかった ${ }^{3)}$. 一方, 生方 ${ }^{4)}$ はムコイド型肺炎球菌のうちペニシリン中 等度耐性肺炎球菌 (PISP : penicillin intermediate-resistant Streptococcus pneumoniae）が増加していることを報告し 耐性化を警告していた. 今回，肺炎球菌のらちムコイド 型でかつ PRSP で，懸命な治療にもかかわらず最終的に
骨導域值の上昇が残存した成人ムコーズス中耳炎例を経 験したので報告する.

\section{症例}

65 歳, 男性.

主訴：左耳痛.

現病歴 : 平成 15 年 8 月中旬, 感冒に罹患し, 8 月 20 日より左耳痛, 耳漏を自覚した。近医耳鼻咽喉科を受診 し急性中耳炎の診断で経口抗生物質（セフェム系）を投 与された。 その後鼓膜切開術も受けたが，耳痛と耳漏が 増悪し, 左耳後部痛も出現したため 9 月 8 日当院紹介と なった。 めまい, 嘔吐, 発熱はなかった。精査加療のた め 9 月 10 日より入院となった.

既往歴 : 十二指腸潰瘍, 高血圧, 糖尿病, 狭心症. 初診時局所所見（図 1）：鼓膜は発赤・膨隆していた. 


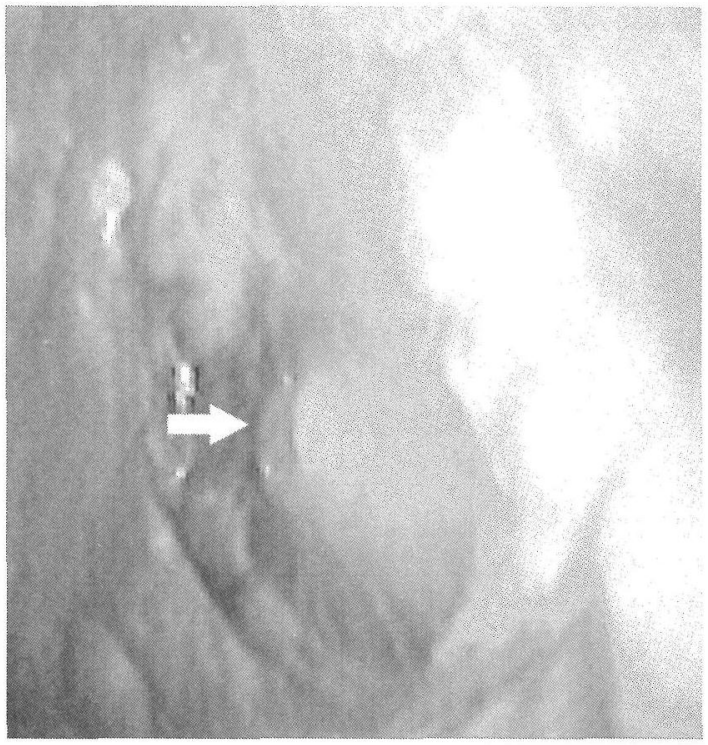

図 1 鼓膜所見

鼓膜全体に発赤と膨隆がみられ，前医での鼓膜切開孔よ り溘出液が漏出している(白矢印)。

前医での鼓膜切開孔より耳漏を拍動性に多量認めた。そ の他, 耳鼻咽喉科領域に異常を認めなかった。

血液検查所見：白血球数 $7100 / \mathrm{mm}^{3}, \mathrm{CRP} 0.93 \mathrm{mg} / \mathrm{dl}$.

耳漏検菌：肺炎球菌が検出された。ムコイド型でから PRSP（大院 2 日後に判明）であった。感受性検査結果を 示す (表 1).

聴力検查（図 2)：純音聴力検查では平均 4 分法聴力レ ベルで右 $23.8 \mathrm{~dB}$ ，左 $91.3 \mathrm{~dB}$ であった。
CT 所見 (図 3): 左右とも乳突蜂巣の発達は良好であっ た。左鼓室, 乳突蜂巣陰影を認めた。

以上よりムコイド型肺炎球菌によるムコーズス中耳炎 と診断された。

入院後経過（図 4）：ペニシリン系抗生剂である piperacillin sodium (PIPC) を 1 日 $2 \mathrm{~g}$ 点滴静注した。左耳痛は 劇的に改善し 2 日間で消失した。耳漏も徐々に軽減した が, 左耳閉感, 左難聴は続くため 9 月 17 日左鼓膜切開術 を施行した。左鼓室内には少量の渗出液を認め, 吸引除 去した。鼓膜切開後も左聴力が平均 4 分法聴力レベルで $73.8 \mathrm{~dB}$ と軽度改善であったため，糖尿病の合併がある ものの急性感音難聴の治療に準じステロイド（ヒドロコ ルチゾンとして $300 \mathrm{mg}$ を 2 日間, $200 \mathrm{mg}$ を 2 日間, $100 \mathrm{mg}$ を 2 日間, 計 6 日かけて漸減投与）を点滴投与し た. 鼓膜切開施行時の滲出液での検菌では菌増殖を認め なかった。退院後，神経賦活剂，ビタミン B12 を投与し， 前医で通気療法（週に 2,3 回）していた。当院での最終 受診時には平均 4 分法聴カレベルが $55.0 \mathrm{~dB}$ となった。 $2000 \mathrm{~Hz}$ 以下の周波数では気骨導差が $20 \sim 30 \mathrm{~dB}$ 存在す るも骨導閾值の上昇が残存した（図 5)。その後も聴力検 査ならびに側頭骨 CT を予定していたが患者が来院せず 平成 15 年 11 月 4 日が最終受診日となりその後の経過は 追跡不可能であった。

\section{考察}

ムコーズス中耳炎の特徴は，激しい耳痛や頭痛，噴出 する耳漏, 急速に進行する難聴, 血液検查（CRP など）

表 1 耳漏の薬剤感受性検査結果

\begin{tabular}{|c|c|c|c|c|c|c|c|c|}
\hline 薬剂略称 & SIR & MIC & 薬刘略称 & SIR & MIC & 薬剤略称 & SIR & MIC \\
\hline PCG & $\mathrm{R}$ & $>4$ & $\mathrm{CMZ}$ & $\mathrm{R}$ & $>16$ & $\mathrm{ABK}$ & 判定基準なし & $\leqq 0.5$ \\
\hline $\mathrm{ABPC}$ & $\mathrm{R}$ & $>4$ & CTRX & $\mathrm{R}$ & $>16$ & ISP & 判定基準なし & 8 \\
\hline AMPC & $\mathrm{R}$ & $>4$ & LMOX & $\mathrm{R}$ & $>16$ & NTL & 判定基準なし & $\leqq 0.5$ \\
\hline PIPC & 判定基準なし & $>32$ & FMOX & $\mathrm{R}$ & $>16$ & CLDM & $\mathrm{R}$ & $>8$ \\
\hline CVA/AMPC & $\mathrm{R}$ & 16 & CFPM & $\mathrm{R}$ & $>16$ & MINO & I & 4 \\
\hline $\mathrm{SBT} / \mathrm{ABPC}$ & 判定基準なし & 4 & $\mathrm{SBT} / \mathrm{CPZ}$ & 判定基準なし & 8 & $\mathrm{CP}$ & $\mathrm{R}$ & 8 \\
\hline $\mathrm{CEZ}$ & $\mathrm{R}$ & $>16$ & $\mathrm{AZT}$ & 判定基準なし & $>16$ & FOM & 判定基準なし & $>16$ \\
\hline CTM & $\mathrm{R}$ & $>8$ & IPM/CS & $\mathrm{R}$ & $>16$ & $\mathrm{VCM}$ & S & 1 \\
\hline $\mathrm{CMZ}$ & $\mathrm{R}$ & $>16$ & MEPM & $\mathrm{R}$ & $>8$ & RFP & 判定基準なし & $\leqq 0.25$ \\
\hline CTX & $\mathrm{R}$ & $>16$ & AMK & 判定基準なし & 8 & CPFX & $\mathrm{R}$ & $>4$ \\
\hline
\end{tabular}

SIR : アメリカ臨床検查標準委員会の基準による $\mathrm{S}$ ：感性 $\mathrm{I}$ ：中間 $\mathrm{R}$ ：耐性 $\mathrm{MIC}$ ：最小発育阻止濃度（微量液体希釈法）（ $\mu \mathrm{g} / \mathrm{ml}$ )

PCG には耐性で，PIPC にも MIC が> 32 であった。 VCM にのみ感性であった。 


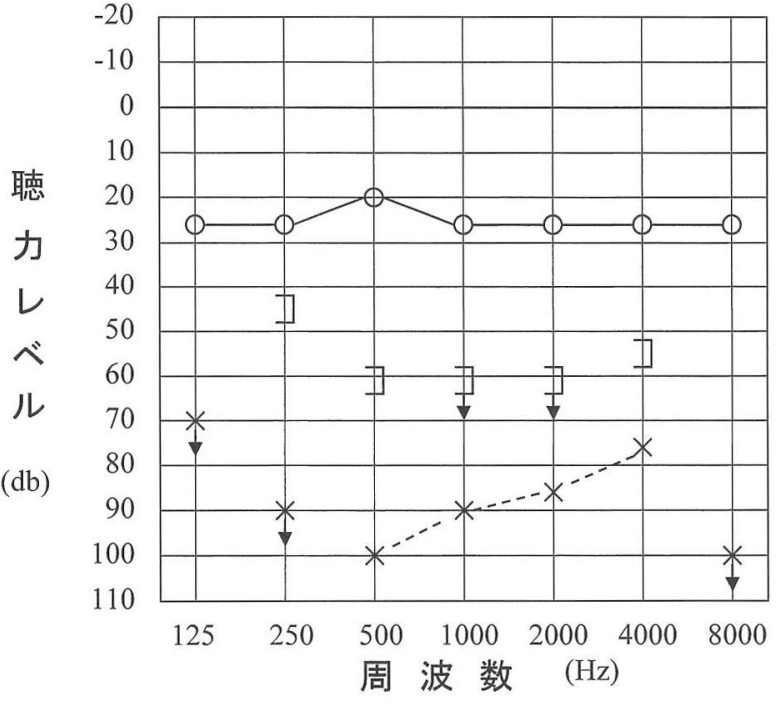

図 2 入院時の純音聴力検查 (平成 15 年 9 月 10 日) 左は高度な混合性難聴を呈した。

で炎症所見陽性などである。ムコーズス中耳炎は抗生剂 が普及して激減したが，1990 年後半より再興の兆しがみ

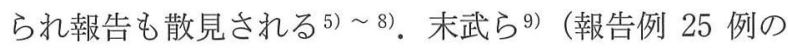
らち詳細な臨床所見が明記されていた入院例9例を検討) と浅野ら ${ }^{10)}$ (成人例 9 例，らち 4 例が入院）の報告例（計 18 例）をむとめると，年齢は $2 \sim 72$ 歳で平均 43.1 歳， 小児例は 2 歳の 1 例のみであった。男性 5 例, 女性 13 例 であった。両側例が 5 例, 一側例が 13 例であった. $37.5^{\circ} \mathrm{C}$ 以上の発熱を認めたのが 8 例 (44.4\%) みられた。 セフェ ム系抗生剂が先行投与されていたのが 9 例（50\%）あっ た。治療は 18 例全例に少なくとも 1 回以上の鼓膜切開術 あるいは鼓膜チューブ㨂入術が施行された。投与された 抗生剂は bacampicillin hydrochloride (ABPC) や piperacillin sodium（PIPC）などのペニシリン系抗生剤であった。ム コーズス中耳炎再興の初期では cefditoren pivoxil (CDTRPI) や cefteram pivoxil (CFTM-PI) が投与された例もあっ た。骨導閾値上昇のためにステロイド使用が 6 例に行わ れたが，最終的に中等度以上の感音難聴が残存した例は なかった。また， S 状静脈洞血栓症を合併し意識障害を きたした例5)や乳突洞削開術施行例6) も報告されている.

アメリカ臨床検查標準委員会 (National committee for clinical laboratory standards：NCCLS）は肺炎球菌をペニ シリン $G$ の最小発育阻止濃度 (minimum inhibitory concentration:MIC) によりペニシリン感性肺炎球菌 (MIC が $0.6 \mu \mathrm{g} / \mathrm{ml}$ 以下 : penicillin-susceptible Streptococcus

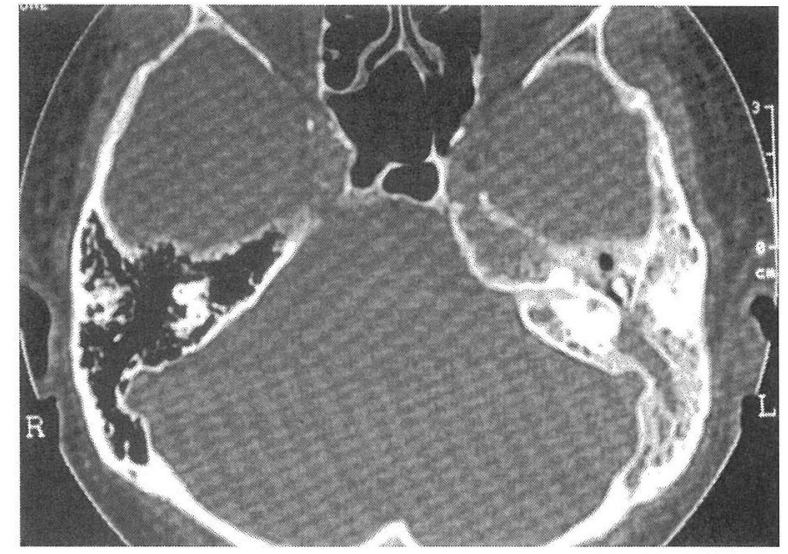

図 3 側頭骨 CT 検查

左鼓室・乳突洞に陰影がみられるが，明らかな骨破壊像 はない.

pneumoniae：PSSP），ペニシリン中等度耐性肺炎球菌 (MIC が $0.1 \sim 1.0 \mu \mathrm{g} / \mathrm{ml}$ : penicillin-intermediate Streptococcus pneumoniae : PISP), ペニシリン耐性肺炎球菌 (MIC が $2 \mu \mathrm{g} / \mathrm{ml}$ 以上: penicillin-resistant Streptococcus pneumoniae：PRSP）に分類している. 肺炎球菌の薬凨耐 性は, $\beta$ - ラクタム剤の標的部位であるペニシリン結合蛋 白 (penicillin binding protein：PBP) に対して薬剤親和性 が低下することにより引き起こされる11) 13)。肺炎球菌

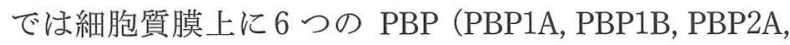
PBP2B, PBP2X, PBP3）があり細胞壁合成を行っている. $\mathrm{PBP}$ に対する $\beta$-ラクタム剤の薬剤親和性の低下はPBP遺 伝子変異（耐性遺伝子： $p b p 1 a, p b p 2 b, p b p 2 x$ ) に上る ${ }^{14)}$. 保有する耐性遺伝子によって, PSSP は $p b p 1 a, p b p 2 b$, $p b p 2 x$ のいずれも保有しない菌, 3 種類すべて保有するの は PRSP，1 種類あるいは 2 種類保有するのが PISP と分 類する報告むある ${ }^{15)}$ 。本邦では $p b p 2 x$ を保有するセフェ 么耐性の肺炎球菌が多いのが特徴である。

一方, 肺炎球菌は培地上のコロニーの発育形態からム コイド型とスムース型に分類されてきた。 また，肺炎球 菌の萊膜の血清型は 80 数種類に分類される ${ }^{16)}$. ヒトの生 体内ではこの萊膜が障害となり他の菌と比べ白血球に圓 食されにくいという特徴がある。莢膜の厚いムコイド型 は 3 型菌が多い。これまでムコイド型は萊膜が厚いため 形質転換しにくく耐性化しにくいといわ机ていた。しか し，生方 ${ }^{415)}$ は 1994 年から 1996 年までの 3 年間では肺 炎球菌のうち約 6 割が PSSP であったが 1998 年から 2000 年の 3 年間では PSSP が約 3 割で残り 7 割は PISP あるい 


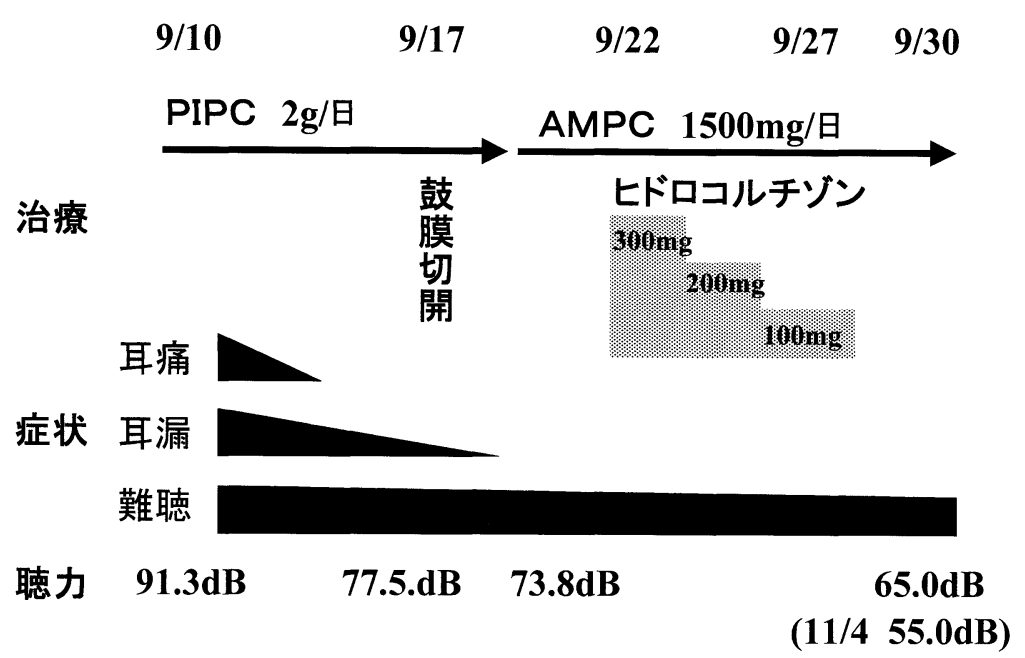

図 4 入院後経過

PIPC : piperacillin sodium, AMPC : amoxicillin

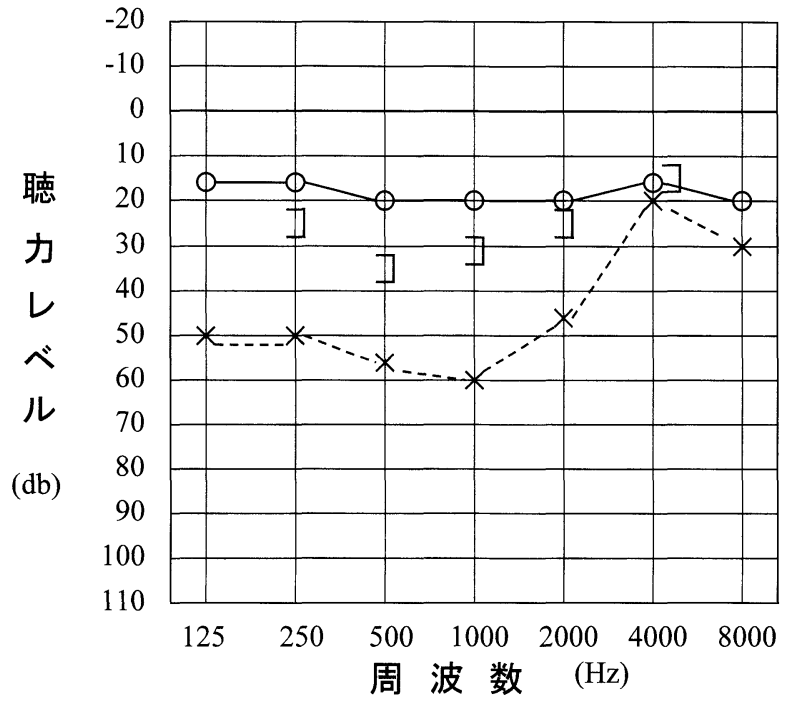

図 5 最終受診時の聴力（平成 15 年 11 月 4 日） 左は骨導閾値の上昇が残存した。

はPRSP となり, 肺炎球菌の $\beta$ - ラクタム剤に対する耐性 化が進行していると報告している．ムコイド型のほとん どは $p b p 2 x$ 変異株で一見ペニシリンに感受性ありという MIC でもセフェム系には軽度の感受性で, 臨床的にはセ フェム系抗生剤はあまり効果がないと警告し, 今後さら に耐性化が進むと予想している ${ }^{4)}$. その予想のとおり, 本 例のようにムコイド型でありながら PRSP という症例が 出現するにいたった。

ムコーズス中耳炎に対する治療は，ムコイド型であれ
ばペニシリンが第一選択である，また，感音難聴を合併 する例ではカルベニン ${ }^{\circledR}$ も推奨されている（）（カルベニ ン ${ }^{\circledR}$ はペニシリンに比べ抗菌力は 10 倍以上).ムコーズ ス中耳炎では初期治療がペニシリン系抗生剤を投与され た例では軽症例が多いのに対し, セフェム系抗生剤投与 例では重症化する例がある. 浅野ら 10) はムコーズス中耳 炎が疑われれば，適切な抗生剤の選択と鼓膜切開術など 外科的処置を躊躇せず施行すべきであると述べている.

本例では入院後にすぐに検査室より耳漏検菌でムコイ ド型肺炎球菌が検出されたといら報告があり，ペニシリ ン系抗生剤である PIPC を使用した。 それが奏効し入院 2 日後には耳痛, 耳漏も軽減した。 その後耳漏の薬剤感 受性検査の結果 PRSP と判明した. PRSP にもかかわら ず，ペニシリン系抗生剤である PIPC が奏効した. 薬剤 感受性検查においても PIPC はMICが $32 \mu \mathrm{g} / \mathrm{dl}$ 以上であっ た. それでも PIPC が奏効した理由として, ペニシリン はセフェム系よりは高い血中濃度が得られ抗菌薬の移行 しにくい中耳への薬剤移行性も良好であり, また, 前医 での鼓膜切開で中耳内の菌量自体が減少していたと予 想される. PRSP に対する PIPC の有効性を報告する文 献17)18）もあるが，もし PIPC が無効であれば，薬剤感受 性検査から考えて感受性を持つvancomycinを使用するこ とになったと推測される.

本例では退院後も近医で通気療法を行い徐々にではあ るが聴力は改善していた. しかしながら退院後は約 1カ 月しか経過観察できなかった. 最終受診時にも $20 \sim 30 \mathrm{~dB}$ 
の気骨導差がみられた，その理由としては，強烈な中耳 内の炎症があったため, 鼓膜と耳小骨の中耳伝音機構に 何らかの悪影響を及ぼしたと推測されるが詳細は不明で ある、最終受診時にはをだ聴力改善の傾向がみられ，耳 閉感や自声強聴もなかったためあえて鼓膜切開術や鼓膜 チューブ挿入術を施行しなかった. むしその後の経過観 察で気骨導差が残るようなことがあれば再度の鼓膜切開 術や鼓膜チューブ挿入術も考慮すべきであったと推測さ れる. また一方，本例では抗生剤投与や鼓膜切開後にも 感音難聴の合併もみられた。 そこで糖尿病もあったが, 急性感音難聴に準じステロイドを点滴静注した。 ただ, 糖尿病の合併があったため内科医とも相談しステロイド は通常使用量よりも減量した。 具体的にはヒドロコルチ ゾンを $300 \mathrm{mg}$ より漸減し計 6 日間投与した。 それにも かかわらず残念ながら本例では骨導閾值の上昇も残存し た.ムコーズス中耳炎例で感音難聴が合併するのは, 他 の急性中耳炎による内耳障害と同様に中耳から蝸牛空や 卵円公を経由して炎症が内耳に波及したと考えられる。 ムコーズス中耳炎では, 突発性難聴のように急に高度な 感音難聴が起こるのではなく, 徐々に内耳障害が起こる と思わ机, 中耳炎から内耳へ障害が及ぶ前に早期診断早 期治療が肝要と思われる.

さて, 今後, 再興感染症としてのムコーズス中耳炎に 遭遇する可能性があるにあたり以下のような注意が必要 である. (1)ムコイド型肺炎球菌が原因のムコーズス中耳 炎の存在を認知しておく, (2)肺炎球菌がスムース型かム コイド型かを微生物検查室より報告してもらう, (3) MIC に基づく薬剤感受性と真の感受性とは必ずしも一致しな いことを認識し，たとえセフェム系抗生剤に薬剤感受性 があったとしてもペニシリンを第一選択とする，(4)鼓膜 切開などの外科的ドレナージを積極的に行う，などがあ る. 今後, より一層耐性菌による中耳炎が増加すると予 想される。それらに対し, 適切な抗生剂使用に加え, 内 耳障害など重症化する前に, 早期にかつ適切に鼓膜切開 などの外科的ドレナージを行うべきであると考える.

\section{まとめ}

65 歳男性のムコーズス中耳炎例につき報告した.

1）起炎菌はムコイド型かつペニシリン耐性肺炎球菌 であった。 ムコイド型肺炎球菌は耐性化しにくいといわ れていたが，ムコイド型でペニシリン耐性は本例が初め ての報告である.
2）PIPC の静脈内投与で耳痛, 耳漏は著明に改善した。 引き続き，鼓膜切開，ステロイド投与を行ったが，骨導 閾值の上昇が残存した。

3）今後とも肺炎球菌の耐性化が進むと予想され, 中耳 炎の治療にあたり, 適切な抗生剂の使用に加え, 鼓膜切 開術など外科的ドレナージを躊躇せずに施行することが 肝要と思われる.

稿を終えるにあたり, 微生物検査にご協力いただきました本 院臨床検查科感染症微生物室松岡喜美子氏に深謝いたします。

本論文の要旨は, 第 289 回日本耳鼻咽喉科学会大阪地方連合 会 (2004 年 6 月, 大阪) で口演した.

\section{参考文献}

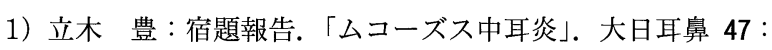
$1786 \sim 1815,1941$.

2）鳥居恵二：ムコーズス（粘液球菌）中耳炎. 日耳鼻全書. 第 1 巻 聴器 第 3 冊 臨床編各論 1 (後藤光治, 高原高 三, 切替一郎, 他編). $64 \sim 73$ 頁, 日本医書出版, 東京, 1953.

3）島田 純: 急性中耳炎の変貌と中耳起炎菌の耐性化の状況. ENTONI 15 (山中 昇編). 1 7 頁, 全日本病院出版会, 東 京, 2002.

4）生方公子：市中感染症研究会・3 年間のまとめ 肺炎球菌 とインフルエンザ菌についての疫学的考察. Jpn J Antibiotics 54 Suppl B : 72 79, 2001.

5）大田隆之, 松井和夫, 小林 斉: ムコーズス中耳炎によっ て生じた $\mathrm{S}$ 状静脈洞血栓症による意識障害の 1 例. 耳鼻臨 床 補 $113: 16,2003$.

6）鈴木聡明：両側の乳突洞開放術を施行したムコーズス中耳 炎の 1 症例. Otol Jpn $12: 253,2002$.

7）今島直俊, 浅野公子, 渋谷恵夏, 他 : 骨導閾値上昇を来し た小児ムコーズス中耳炎新鮮症例. Otol Jpn 13:411, 2003.

8）藤村和伸, 寶地信介, 藤吉達也, 他：両耳で異なる臨床経 過をたどったムコーズス中耳炎症例. Otol Jpn $13:$ 503, 2003.

9）末武光子, 入間田美保子, 高橋 辰, 他：ムコーズス中耳 炎の現況と問題点. Otol Jpn $10: 89 \sim 94,2002$.

10）浅野公子, 今島直俊, 渋谷恵夏, 他 : ムコーズス中耳炎成 人新鮮症例. Otol Jpn $13: 209 \sim 213,2003$.

11) Spratt $B G$ : Resistance to antibiotics mediated by target alterations. Science $264: 388 \sim 393,1994$.

12) Hakenbeck $R$, Tarpay $M$ and Tomasz $A$ : Multiple changes of penicillin-binding proteins in penicillin-resistant clinical isolates Streptococcus pneumoniae. Antimicrob Agents Chemother $17: 364 \sim 371,1980$. 
13) Hakenbeck R, Ellerbrok $H$, Briese $T$, et al. : Penicillin -binding proteins of penicillin-susceptible and resistant pneumococci: immunological relatedness of altered proteins and changes in peptides carrying the $\beta$-lactam binding site. Antimicrob Agents Chemother $30: 553 \sim 558,1980$.

14）紺野昌俊, 生方公子：VII. PRSP におけるペニシリン, セ フェム系薬耐性機構. ペニシリン耐性肺炎球菌. $83 \sim 98$ 頁，（株）協和企画通信，東京，1997.

15）生方公子：再検討が迫られる市中感染症，細菌検查の立場 から. Jpn J Antibiotics 52 Suppl B : 4 13, 1999.

16）紺野昌俊，生方公子：V. 肺炎球菌の血清型と病原性. ヘ ニシリン耐性肺炎球菌. 55 〜 68 頁，（株）協和企画通信， 東京, 1997.
17）松崎 薰, 小山英明, 大美賀薰, 他：呼吸器感染症由来の 各種耐性菌に対する Piperacillin 抗菌活性一MRSA, PRSP, BLNAR, P. aeruginosa を中心に一. Jpn J Antibiotics $53: 566$ $\sim 572,2000$.

18) Hori $R$, Araki $H$, Yonezawa $M$, et al. : Therapeutic effects of parenteral $\beta$-lactam antibiotics on experimental otitis media caused by penicillin-resistant Streptococcus pneumoniae in guinea-pig. J Antimicrob Chemother $45: 311 \sim 314,2000$.

原稿受付：平成16年 7 月 22 日

原稿採択：平成16年 9 月 1 日

別刷請求先：成尾一彦

于558-8558 大阪市住吉区万代東3-1-56

大阪府立急性期・総合医療センター耳鼻咽喉科 